\title{
Lymphocyte and neuronal antigens in neuropsychiatric lupus: presence of an elutable, immunoprecipitable lymphocyte/neuronal $52 \mathrm{kd}$ reactivity
}

Judah A Denburg, Sharon A Behmann

\begin{abstract}
Objective-To examine specific lymphocyte or neuronal antigens immuno-precipitated by systemic lupus erythematosus (SLE) sera.

Method-SLE sera were screened for the presence of antibodies binding to surface antigens of CD4(+) HUT-78 or SK-N-SH and IMR-6 neuroblastoma cells using Western blotting or radioimmunoprecipitation.

Results-IgG eluates from both lymphocytes and neuroblastoma cells recognised a $52 \mathrm{kd}$ band in HUT 78 cell lysates. Eight sera studied further using radioimmunoprecipitation also demonstrated binding to a $52 \mathrm{kd}$ antigen (4/8 on HUT-78, 8/8 on SK-N-SH cells), partially depleted by absorption with viable HUT-78.

Conclusion-A $52 \mathrm{kd}$ antigen recognised by SLE sera on lymphocytes and neuronal cells may play a role in the pathogenesis of neuropsychiatric-SLE.
\end{abstract}

(Ann Rheum Dis 1994; 53: 304-308)

Sera from patients with systemic lupus erythematosus (SLE) are reactive with many cellular antigens. ${ }^{1-3}$ Attempts to show positive correlations between autoantibodies and disease parameters are often met with frustration; some associations have been found, ${ }^{4-10}$ but a reliable relationship between NP-SLE and cell-surface antigens is yet to be delineated. Technical problems in acquiring pure antigen preparations and the heterogeneity of antibody specificities in SLE sera can be compounded by low-avidity binding and small amounts of cell-surface antigens. In NPSLE, particular interest has been given to cross-reacting antigens on lymphocytes and neuronal cells. ${ }^{781011}$ For the well-characterised intracellular protein antigens such as DNA, Ro, La, Sm and RNP, ${ }^{12} 1213$ there is some evidence of their presence on cell surfaces in vitro, but it is unclear whether or not their appearance is transient and/or relevant in vivo. ${ }^{14}$ The investigation presented here is an attempt to characterise which, if any, of the above antigens might be useful markers of NP-SLE; the presence of a lymphocyte/neuronal $52 \mathrm{kd}$ reactivity is documented. Immunoprecipitation experiments are performed to further clarify this lymphocyte and neuronal $52 \mathrm{kd}$ moiety.

\section{Materials and methods}

PATIENTS AND SERA

Venous blood was obtained from patients attending the McMaster University Medical Centre Lupus Clinic who met the 1982 American Rheumatism Association revised criteria ${ }^{15}$ for classification as SLE. After separation from blood, serum was aliquoted and stored at $-70^{\circ} \mathrm{C}$.

\section{CELL CULTURE}

HUT-78, a CD4+ human lymphoblastoid T lymphocyte cell line ${ }^{16}$ was used as a source of lymphocyte antigens. Cells were passaged as a non-adherent culture and maintained in RPM1 1640 with 10\% FCS, HEPES and glutamine. The human neuroblastoma cell lines SK-N-SH (provided by J Fogh, SloanKettering Cancer Research Institute, New York, NY) and IMR-6 (from R Kennett, Department of Genetics, University of Pennsylvania, Philadelphia, PA) were passaged as a monolayer ${ }^{5}$ and maintained in RPM1 1640 with $10 \%$ FCS and non-essential amino acids. All cultures were grown at $37^{\circ} \mathrm{C}$ in $5 \%$ $\mathrm{CO}_{2}$ in air, in a humidified atmosphere. Platelets were provided by Dr J Kelton, McMaster University.

\section{PREPARATION OF DETERGENT LYSATES OF} HUT-78 AND SK-N-SH CELLS

HUT-78 cells were harvested and washed three times with Hanks balanced salt solution (HBSS) before solubilisation in $\mathrm{PO}_{4}$ buffer (pH 7.2) containing $1 \%$ Triton X-100 (Bio RAD), $2 \mathrm{mM}$ phenylmethyl-sulfonyl fluoride (Sigma), and 1 trypsin inhibitory $\mathrm{U} / \mathrm{ml}$ aprotinin. Approximately $1 \times 10^{7}$ cells per $\mathrm{ml}$ of lysis buffer were incubated for one hour on ice with occasional vortexing. SK-N-SH cells were solubilised after release from culture with $0.02 \%$ EDTA and three washes with HBSS. Lysates were cleared of nuclei by centrifugation at $400 \times \mathrm{G}$ for 10 minutes at $4^{\circ} \mathrm{C}$. Cytoskeletal components and unsolubilised membranes were removed by ultracentrifugation at $100000 \mathrm{~g}$ for 60 minutes at $4^{\circ} \mathrm{C}$ Aliquoted lysate was stored at $-70^{\circ} \mathrm{C}$ until use. 
WESTERN BLOTTING

Prepared lysates of SK-N-SH or HUT-78 (representing $\sim 6 \times 10^{6}$ cells) were boiled for five minutes in SDS sample buffer $[50 \mathrm{mM}$ Tris- $\mathrm{HCl}$ ( $\mathrm{pH} 6 \cdot 8$ ), 2\% sodium dodecyl sulphate (SDS; BIORAD) and 10\% glycerol] and electrophoresed under non-reducing conditions using $12 \%$ SDS-polyacrylamide slab gels according to the technique of Laemmli. ${ }^{17}$ Prestained marker proteins (Bethesda $\mathrm{Re}-$ search) were used to calibrate molecular weight. Electrotransfer of proteins to nitrocellulose sheets ${ }^{18}$ was performed overnight at a constant power of 30 volts in transfer buffer [20 mM Tris- $\mathrm{HCl}$ (pH 8.2), $150 \mathrm{mM}$ glycine, $20 \%$ methanol, $0.01 \%$ SDS] using a BIORAD Trans-Blot cell.

Nitrocellulose strips were incubated for two hours at room temperature in blocking buffer [20 mM Tris- $\mathrm{HCl}$ (pH 7.4), $200 \mathrm{mM} \mathrm{NaCl}$, $0.05 \%$ Tween 80 , and $5 \%$ skim milk powder], washed twice in $20 \mathrm{mM}$ Tris- $\mathrm{HCl}(\mathrm{pH} \mathrm{7.4})$, $200 \mathrm{mM} \mathrm{NaCl}, 0.05 \%$ Tween 80 , and incubated for 60 minutes at room temperature with constant agitation in test sera at a 1:25 dilution. The strips were washed three times before the addition of alkaline-phosphatase conjugated goat anti-human IgG $(\mathrm{H} \& \mathrm{~L})$ (Biocan Scientific) which was incubated for 60 minutes at room temperature. After three more washes, the strips were developed for colour with BCIP/NBT (BIO-RAD) solution.

\section{ELUATES}

Eluates $^{19}$ were prepared from HUT-78, SKN-SH, IMR-6 and platelets by mixing $0.5 \mathrm{ml}$ serum diluted 1:2 with RPM1 with $12-15 \times 10^{7}$ cells which had been fixed in 3\% paraformaldehyde and incubating overnight at $4^{\circ} \mathrm{C}$ with gentle mixing. The cells were washed three times in RPM 1 at $4^{\circ} \mathrm{C}$ followed by incubation at $37^{\circ} \mathrm{C}$ in $\mathrm{RPM} 1$ for one hour with gentle agitation. Eluates and supernates were stored at $-70^{\circ} \mathrm{C}$ until used.

RADIOLABELLING

Surface proteins on HUT-78 and SK-N-SH cells were labelled by solid-phase lactoperoxidase/glucose oxidase-catalysed radioiodination using Enzymobeads (BIO-RAD) according to the manufacturer's instructions. Approximately $1 \times 10^{7}$ cells in $250 \mu$ l of HBSS were combined with $25 \mu \mathrm{l}$ of $0.5 \mathrm{M}$ phosphate buffer ( $\mathrm{pH} \mathrm{7.2),} 50 \mu \mathrm{l} \mathrm{1 \% \beta -D-glucose,} 0.5$ $\mathrm{mCi}$ sodium ${ }^{125} \mathrm{I}$ and $50 \mu \mathrm{l}$ Enzymobeads. Following incubation at room temperature for 60 minutes, the cells were washed three times in PBS ( $\mathrm{pH} \mathrm{7.4)}$ ) and solubilised in lysing buffer as described for preparation of detergent lysates.

IMMUNOPRECIPITATION AND SDS-PAGE Preclearance of cell lysates with protein A-Sepharose beads (Pharmacia) did not result in any reduction in non-specific binding and was omitted in these experiments. Aliquots of $300-500 \mu l$ of cell lysate were incubated with
$30 \mu l$ of test serum overnight at $5^{\circ} \mathrm{C}$ with gentle mixing. Immune complexes were removed by the addition of $10 \%$ protein A-Sepharose beads and incubating for a further three hours at $5^{\circ} \mathrm{C}$. The beads were washed 5 times in lysis buffer and the complexes dissociated by boiling for five minutes in non-reducing SDS sample buffer. The denatured proteins were electrophoresed by using $12 \%$ SDS-polyacrylamide slab gels under non reducing conditions ${ }^{17}$ along with prestained molecular weight markers. (Bethesda Research). Gels were fixed in $40 \%$ methanol: $10 \%$ Acetic acid; 5\% glycerol, then dried and autoradiographed with XAR-5 film (Eastman Kodak) for 5-7 days at $-70^{\circ} \mathrm{C}$.

IMMUNOABSORPTION

HUT-78 and SK-N-SH cells were harvested and washed three times in HBSS to obtain final pellets of $5 \times 10^{7}$ cells with $>90 \%$ viability as determined by nuclear exclusion of trypan blue. Cell pellets were resuspended in $1 \mathrm{ml}$ of SLE serum variously diluted with RPM1 according to mixed haemadsorption assay (MHA) $)^{5}$ titre and incubated for one hour at room temperature followed by at least two hours at $5^{\circ} \mathrm{C}$. The procedure was repeated sequentially three times. The final supernatant and diluted serum controls were aliquoted and stored at $-70^{\circ} \mathrm{C}$ until further use.

\section{MIXED HAEMADSORPTION ASSAY}

The MHA which has been previously described $^{5}$ and is routinely carried out in this laboratory to screen for the presence of IgG antineuronal antibodies in sera is defined as positive reactivity to one or more neuroblastoma cell lines at a titre $\geq 1: 20$. HUT-78 cells as well as neuroblastomas were used in this assay system to test the effectiveness of absorption procedures and the possibility of cross-reactivity with lymphocytes and neuronal cells.

\section{LYMPHOCYTOTOXICITY}

Cold reactive anti-lymphocyte (LCA) antibodies were measured by a modification of the micro-droplet method as previously described $^{20}$ and $T$ cell 30 frozen cell trays (Gen Trak). Sera and cells were incubated for one hour at $4^{\circ} \mathrm{C}$ followed by the addition of rabbit complement (Gen Trak) and incubation for one hour at $15^{\circ} \mathrm{C}$. Results are expressed as a percentage of cells killed.

\section{Results}

ELUATE REACTIVITIES WITH LYMPHOCYTES AND NEURONAL CELLS

Serum from a patient with active NP-SLE was used in eluate experiments with HUT-78, SKN-SH, IMR-6 cells and platelets. Absorption with HUT-78 cells removed most of the $52 \mathrm{kd}$ activity which was recoverable in the eluates (fig 1A). Eluates from the neuroblastoma cell lines SK-N-SH and IMR-6 also demonstrated 

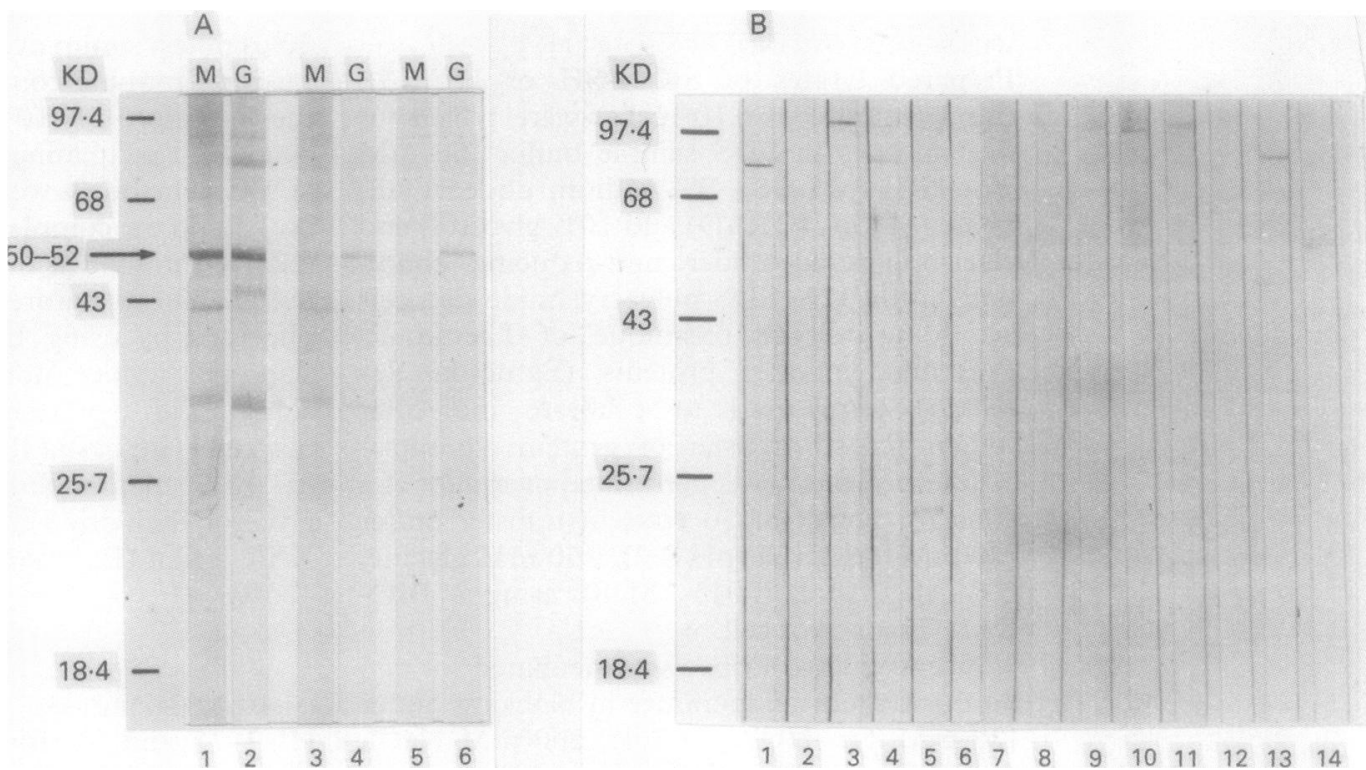

Figure 1 (A) Immunoblots showing $\operatorname{Ig} M(M)$ or $\operatorname{Ig} G(G)$ reactivities in SLE sera, using goat anti-human IgG or IgM, to 50-52 kd and other proteins on HUT-78 cells. An arrow indicates the 50-52 kd protein band. Lanes 1 and 2, unabsorbed sera; lanes 3 and 4, partially absorbed with HUT-78 cells; lanes 5 and 6, eluates; (B) Control sera showing, with one exception (lane 14), no 52 kd reactivity on immunoblotting of IMR-6 lysates. Lanes 1-6, normal human sera; Lanes 7-14, rheumatoid arthritis sera.

a $52 \mathrm{kd}$ reactivity both in serum and eluate; absorption was incomplete (fig 2). All of the eluates except those from platelets demonstrated LCA activity, but neuronal antibodies were absent except in IMR-6 (table 1). Control sera $(n=43)$ were studied from healthy volunteers or patients with rheumatoid arthritis. Some representative examples of these are shown in fig 1B: $13 / 14$ (93\%) were devoid of the $52 \mathrm{kd}$ reactivity on either HUT-78 or IMR-6 lysates.

IMMUNOPRECIPITATION OF LABELLED SURFACE PROTEINS ON LYMPHOCYTES AND NEURONAL

CELLS.

In immunoprecipitation experiments, the lysates of $\mathrm{I}^{125}$ surface labelled HUT-78 and SK-N-SH cells were incubated with a panel of $8 \mathrm{NP}-\mathrm{SLE}$ sera previously used in Western blotting of SK-N-SH lysates, and run in SDSPAGE. With HUT-78 lysate, four of the sera precipitated a $52 \mathrm{kd}$ band, 2 precipitated a $55 \mathrm{kd}$ band, whereas all eight sera precipitated a $52 \mathrm{kd}$ band with SK-N-SH (fig 3). None of the sera precipitated a $32 \mathrm{kd}$ band against either cell line, and $55 \mathrm{kd}$ was not detected on SK-N-SH with any sera, in contrast to Western blotting results. ${ }^{11}$ This lack of expression of $55 \mathrm{kd}$ is consistent with previous work in our laboratory (unpublished) using $\mathrm{I}^{125}$ labelled neuroblastoma lysates and SLE sera. Table 2 summarises Western blotting and immunoprecipitation experiments.

IMMUNOABSORPTION STUDY

Immunoabsorption experiments were carried out with 4 NP-SLE sera showing $52 \mathrm{kd}$ reactivity, using viable HUT-78 and SK-N-SH cells to confirm the specificity of the $52 \mathrm{kd}$ antigen and to further investigate crossreactivity. The mixed haemadsorption assay

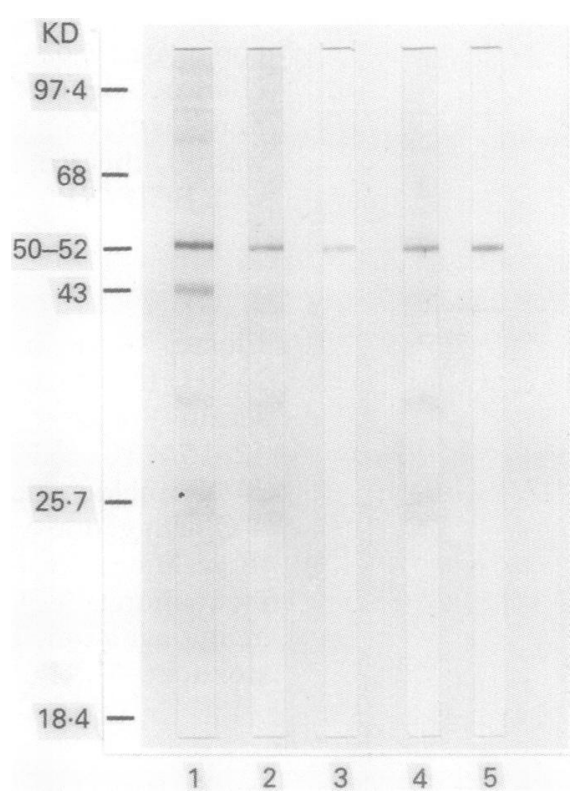

Figure 2 Immunoblots showing IgG reactivities in SLE sera to 50-52 kd proteins on neuroblastoma cells. Lane 1, unabsorbed serum; Lane 2, absorbed with SK-N-SH cells; Lane 3, eluate from $S K-N-S H$ cells; Lane 4, absorbed with IMR-6 cells; Lane 5, eluate from IMR-6 cells.

was used to test binding activity before and after absorption. Absorption of LCA by HUT-78 cells was demonstrated in two sera. Neuronal antibody was absorbed from two of the four sera, only by SK-N-SH (table 3).

\section{Discussion}

The causal role for antibodies directed against cross-reactive, brain-lymphocyte antigens in the pathogenesis of nervous system lupus (NP-SLE) has not yet been determined. Various investigators have proposed roles for neuronal, ${ }^{4521}$ lymphocytotoxic, ${ }^{7} 91022$ ribosomal $\mathrm{P}_{2}^{23}$ phospholipid ${ }^{24}{ }^{25}$ and glycolipid ${ }^{26} 27$ antibodies in the pathogenesis of NP-SLE, based 
on correlations between these antibodies and clinical NP-SLE.

In the current studies, we have attempted to further identify common lymphocyte and neuronal antigens recognised by some SLE sera. This derived from observations on the presence of reactivities to a $50-55 \mathrm{kd}$ as well as a $32-34 \mathrm{kd}$ series of antigens in relation to NP-SLE and, possibly, to cognitive dysfunction. ${ }^{11}$ We found serum reactivity by Western blotting to $31-32 \mathrm{kd}, 50-52 \mathrm{kd}$ and 54-55 kd antigens using $\mathrm{CD}^{+}$, HUT-78 lymphocytes, as well as SK-N-SH neuroblastoma cells. In the current report, the eluates prepared from HUT-78 (lymphocyte line), IMR-6 and SK-N-SH cells (neuroblastoma lines), in contrast to platelet eluates, showed consistent precipitation by IgG antibodies of a $52 \mathrm{kd}$ band; this was especially marked using HUT-78 cell eluates. This $52 \mathrm{kd}$ band was also recognised by a panel of eight sera studied in immunoprecipitation experiments with $I^{125}$ labelled lymphocytes or neuronal cells (fig 3 ). While these studies were

Table 1 Lymphocytotoxic and neuronal reactivities of eluates demonstrating a $52 \mathrm{kd}$ stained band from NP-SLE serum.

\begin{tabular}{|c|c|c|c|}
\hline & \multirow{2}{*}{$\begin{array}{l}\begin{array}{l}\text { Lymphocyte } \\
\text { reactivity }\end{array} \\
\text { LCA-HUT-78 }\end{array}$} & \multicolumn{2}{|c|}{ Neuronal reactivity ${ }^{\star \star}$} \\
\hline & & $S K-N-S H$ & $I M R-6$ \\
\hline $\begin{array}{l}\text { NP-SLE serum ( } 1: 2 \text { dilution) } \\
\text { HUT-78 eluate } \\
\text { SK-N-SH eluate } \\
\text { IMR- } 6 \text { eluate }\end{array}$ & $\begin{array}{l}97 \\
60 \\
42 \\
57\end{array}$ & $\begin{array}{l}++ \\
- \\
- \\
+\end{array}$ & $\begin{array}{l}++++ \\
- \\
- \\
-\end{array}$ \\
\hline
\end{tabular}

*Lymphocytotoxicity expressed as \% killing of HUT-78 cells.

$\star \star$ Neuronal Antibody scores as: $-<10 \%$ positive cells; $+10-25 \%$ positive cells; $++26-50 \%$ positive cells; $+++51-75 \%$ positive cells; $++++76-100 \%$ positive cells.

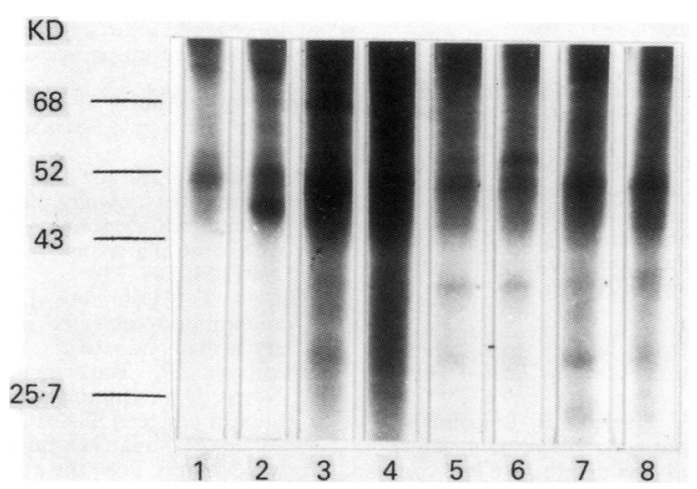

Figure 3 Immunoprecipitation of antigens on $I^{125}$ surfacelabelled HUT-78 and SK-N-SH cells by SLE sera. Lanes $1-8$, sera from individual patients; a $52 \mathrm{kd}$ reactivity is present in each case. not performed in a large number of SLE sera, they may nonetheless point out a potential shared lymphocyte/neuronal surface antigen of interest. More definitive, prospective evaluation of this reactivity in a patient cohort is in progress. While indications are that a 50-52 kd immunoreactivity by Western blotting is significantly associated with NPSLE, ${ }^{11}$ anti-Ro antibodies by ELISA per se do not correlate with NP-SLE but the presence of both anti-Ro and anti-50/52 kd appears to be associated with NP-SLE; for example, of 11 sera with both Ro and 50/52 kd reactivities, eight $(73 \%)$ had NP-SLE, as opposed to $16 / 37$ $(43 \%)$ of sera with Ro-reactivity alone.

Since a significant proportion (37/99 or $37 \%$ ) of these sera contained anti-Ro reactivity by ELISA, and since 5/6 50-52 kd reactive sera tested in eluate studies were also Ro $(+)$ ve, the possibility exists that the activity seen here in the eluates, as well as directly by radiolabelled immunoprecipitation, represents an anti-52 kd Ro specificity. Numerous investigators have recently commented on the large number of molecular forms of Ro and the genetic polymorphisms encoding this cytoplasmic molecule. ${ }^{121213}$ While $52 \mathrm{kd}$ Ro is not normally a component found to be reactive in the immunoassays performed in clinical laboratories, Western blotting may reveal it. ${ }^{12}$ Thus it is possible that the lymphocyteneuronal antigen precipitated by our lupus sera is indeed $52 \mathrm{kd} \mathrm{Ro,} \mathrm{although} \mathrm{definitive}$ molecular proof of this is still lacking. The presence of this antigen on the surface of cells, while not commonly recognised, is possible. Ro can be expressed on the surface of cells such as keratinocytes after ultraviolet radiation and on embryonic cardiac muscle, ${ }^{28}$ forming the basis for the possible relationships of congenital heart block and photosensitive skin rash with Ro. ${ }^{13}{ }^{14}$ Whether or not $52 \mathrm{kd}$ Ro can be expressed on the surface of neuronal cells and is related to NP-SLE is still unclear. Recently, a ribosomal $P_{o}$ antigen has been shown to be expressed on the surface of SK-N-MC cells; however, the molecular size of this antigen was $38 \mathrm{kd}^{28}$

There are several observations in recent reports which speculate on the role of Ro in the possible pathogenesis of certain forms of developmental abnormalities of the nervous system, including dyslexia. ${ }^{30}$ Indeed, an autoimmune hypothesis of learning disabilities, involving the Ro antigen and based upon a

Table 2 Pattern of SLE sera reactivities with lymphocytic and neuronal cell lines by Western blotting (WB) and radioimmunoprecipitation

\begin{tabular}{|c|c|c|c|c|c|c|c|c|}
\hline \multirow[t]{2}{*}{ Serum } & \multicolumn{3}{|c|}{$\begin{array}{l}\text { HUT-78 (WB) } \\
\text { kd bands }\end{array}$} & \multicolumn{2}{|c|}{$\begin{array}{l}\text { HUT-78 }\left(I^{125}\right) \\
\text { kd bands }\end{array}$} & \multicolumn{2}{|c|}{$\begin{array}{l}S K-N-S H(W B) \\
k d \text { bands }\end{array}$} & \multirow{2}{*}{$\begin{array}{l}S K-N-S H\left(I^{25}\right) \\
\text { kd bands } \\
52\end{array}$} \\
\hline & 32 & 52 & 55 & 52 & 55 & 32 & 52 & \\
\hline $\begin{array}{l}1 \\
2 \\
3 \\
4 \\
5 \\
6 \\
7 \\
8\end{array}$ & $\begin{array}{l}\mathrm{X} \\
\mathrm{X} \\
\mathrm{X}(\mathrm{d}) \\
\mathrm{X} \\
\mathrm{X} \\
\mathrm{X}\end{array}$ & $\begin{array}{l}\mathbf{X} \\
\mathbf{X} \\
\mathbf{X} \\
\mathbf{X} \\
\mathbf{X} \\
\mathbf{X} \\
\mathbf{X}\end{array}$ & $\underset{\mathrm{X}}{\mathrm{X}}$ & $\begin{array}{l}\mathrm{X} \\
\mathbf{X}\end{array}$ & $\mathrm{x}$ & $\begin{array}{l}X(d) \\
\text { not available }\end{array}$ & $\begin{array}{l}\text { X (very weak) } \\
\text { X (very weak) } \\
\text { X (very weak) } \\
\text { X }\end{array}$ & $\begin{array}{l}\mathbf{X} \\
\mathbf{X} \\
\mathbf{X} \\
\mathbf{X} \\
\mathbf{X} \\
\mathbf{X} \\
\mathbf{X} \\
\text { X }\end{array}$ \\
\hline
\end{tabular}

$\mathrm{X}$-indicates presence of band.

(d) -indicates presence of doublet. 
Table 3 Results of absorption experiments with 4 NP-SLE sera and HUT-78 and SK-N-SH cells in mixed haemadsorption assay

\begin{tabular}{|c|c|c|c|c|c|c|}
\hline \multirow[t]{2}{*}{ Serum } & \multicolumn{3}{|c|}{ Lymphocyte antibody* } & \multicolumn{3}{|c|}{ Neuronal antibody ${ }^{\star}$} \\
\hline & Pre-abs & $\begin{array}{c}\text { Abs with } \\
H U T-78\end{array}$ & $\begin{array}{l}\text { Abs with } \\
S K-N-S H\end{array}$ & Pre-abs & $\begin{array}{l}\text { Abs with } \\
H U T-78\end{array}$ & $\begin{array}{l}\text { Abs with } \\
S K-N-S H\end{array}$ \\
\hline $\begin{array}{l}1 \\
2 \\
3 \\
4\end{array}$ & $\begin{array}{l}++++ \\
+ \\
++++ \\
-\end{array}$ & $\begin{array}{l}+ \\
+ \\
- \\
-\end{array}$ & $\begin{array}{l}++++ \\
+ \\
++++ \\
-\end{array}$ & $\begin{array}{l}+ \\
++++ \\
++++ \\
++\end{array}$ & $\begin{array}{l}++ \\
++++ \\
+++ \\
+\end{array}$ & $\begin{array}{l}++ \\
+++ \\
- \\
-\end{array}$ \\
\hline
\end{tabular}

^Scoring of wells: $-<10 \%$ positive cells; $+10-25 \% ;++26-50 \% ;+++51-75 \% ;++++76-100 \%$ positive cells. abs-absorption.

finding of increased left-handedness and dyslexia in autoimmune disease populations, or vice-versa ${ }^{30}{ }^{31}$ has been proposed. Our study sample was too small and uncontrolled to draw any conclusions concerning the role of Ro in NP-SLE or the specific cognitive abnormalities which can be associated with it. ${ }^{21}$ The possible relationship of NP-SLE or cognitive dysfunction with specific lymphocyte reactivities, and especially with a $50-52 \mathrm{kd}$ reactivity, ${ }^{11}$ however, suggests that surface expression of Ro or molecularly related antigens may be involved in the development of NP-SLE and cognitive dysfunction in some patients with SLE. One new neuronal antigen recently shown to be a target of SLE sera, especially in patients with nervous system involvement, is a $50 \mathrm{kd}$ protein whose function has yet to be determined. ${ }^{32}$

More work certainly needs to be done on clarifying conditions leading to surface expression of Ro on normal human nervous system components, including neuronal cells, and its relationship to the development of behavioural and cognitive abnormalities. The availability recently of an animal model of cognitive dysfunction in $\mathrm{SLE}^{33}$ may make this hypothesis directly testable.

The invaluable assistance of Katheryne Stewart and the staff of the Lupus Clinic at McMaster Hospital is gratefully acknowledged; Lynne Larocque carefully proof read and edited the manuscript. The continued advice of Drs Susan Denburg and Ramona Carbotte has been of great assistance in the preparation of the manuscript.

preparation of the manuscript. of Canada, the Ontario Lupus Association, the Lupus Society of Hamilton, and the Ontario Ministry of Health.

1 Hardin J A. The lupus autoantigens and the pathogenesis of systemic lupus erythematosus. Arthritis Rheum 1986; 29: $457-60$.

2 Rader M D, O'Brien C, Liu Y, Harley J B, Reichlin M. Heterogeneity of the Ro/SSA antigen. Different molecular forms in lymphocytes and red blood cells. $尹$ Clin Invest 1989; 83: 1293-8.

3 Elkon K B, Bonfa E, Llovet R, Eisenberg R A. Association between anti-Sm and anti-ribosomal $P$ protein autoantibodies in human systemic lupus erythematosus and MRL/1 pr mice. F Immunol 1989; 143: 1549-54.

4 Hanly J G, Rajaraman S, Behmann S, Denburg J A. A nove neuronal antigen identified by sera from patients with systemic lupus erythematosus. Arthritis Rheum 1988; 31: 1492-9.

5 How A, Dent P B, Liao S-K, Denburg J A. Antineurona antibodies in neuropsychiatric systemic lupus erythematosus. Arthritis Rheum 1985; 28: 789-95.

6 Kelly M C, Denburg J A. Cerebrospinal fluid immunoglobulins and neuronal antibodies in neuropsychiatric systemic lupus erythematosus and related conditions. f Rheumatol 1987; 14: 740-4.

7 Long A A, Denburg S D, Carbotte R M, Singal D P Denburg J A. Serum lymphocytotoxic antibodies and neurocognitive function in systemic lupus erythematosus. Ann Rheum Dis 1990; 49: 249-53.
8 Bluestein H J G, Zvaifler N J. Brain-reactive lymphocytotoxic antibodies in the serum of patients with systemic cytotoxic antibodies in the serum of patients with system
lupus erythematosus. $\mathcal{F}$ Clin Invest 1976; 57: 509-16.

9 Bresnihan B, Oliver M, Grigor R, Hughes G R V. Brain reactivity of lymphocytoxic antibodies in systemic lupus erythematosus with and without cerebral involvement. Clin Exp Immunol 1977; 30: 333-7.

10 Temesvari P, Denburg J, Denburg S, Carbotte R, Benson W, Singal D. Serum lymphocytotoxic antibodies in neuropsychiatric lupus: a serial study. Clin Immunol Immunopathol 1983; 28: 243-51.

11 Denburg S D, Behmann S A, Carbotte R M, Denburg J A. Lymphocyte antigens in neuropsychiatric lupus: Relationship of lymphocytotoxic antibody specificities to clinical disease. Arthritis Rheum (in press).

12 Ben-Chetrit E, Fox R I, Tan E M. Dissociation of immune responses to the SS-A (Ro) $52-\mathrm{Kd}$ and $60-\mathrm{Kd}$ polypeptides in systemic lupus erythematosus and polypeptides in systemic lupus erythematosus and

13 Itoh H, Rader M D, Reichlin M. Heterogeneity of the Ro/SSA antigen and autoanti-Ro/SSA response: evidence of the four antigenically distinct forms. Clin Exp Immunol 1990; 81: 45-51.

14 Muso E, Jacob L. A polyspecific monoclonal anti-DNA autoantibody also binds to cell-surface protein(s). Clin Immunol Immunopathol 1987; 42: 370-4.

15 The ARA Subcommittee for SLE Criteria. The 1982 revised criteria for the classification of systemic lupus erythematosus. Arthritis Rheum 1982; 25: 1271-7.

16 Gazdar A F, Carney D N, Bunn P A, et al. Mitogen requirements for the in vitro propagation of cutaneous requirements for the in vitro propagation

17 Laemmli UK. Cleavage of structural proteins during the assembly of the head of bacteriophage T4. Nature 1970; 277: $680-5$.

18 Towbin H T, Staehelin T, Gordon J. Electrophoretic transfer of proteins from polyacrylamide gels to nitrocellulose sheets: procedure and source applications. Proc Natl Acad Sci USA 1979; 76: 4350-4.

19 Pruzanski W, Armstrong M, Urowitz M B. Cytotoxic activity of cerebrospinal fluids (CSF's) against lymphocytes and phagocytes: comparison of normal and systemic lupus erythematosus CSF's. 7 Rheumatol 1979; 6: 259-69.

20 Terasaki P I, McClelland J D. Microdroplet assay of human serum cytotoxins. Nature 1964; 204: 998-1000.

21 Denburg J A, Carbotte R M, Denburg S D. Neuronal antibodies and cognitive function in systemic lupus erythematosus. Neurology 1987; 37: 464-7.

22 Denburg S D, Carbotte R M, Long A A, Denburg J A. Neuropsychological correlates of serum lymphocytotoxic antibodies in systemic lupus erythematosus. Brain Behav Immun 1988; 2: 222-34.

23 Bonfa E, Golombek S J, Kaufman L D, et al. Association between lupus psychosis and anti-ribosomal $P$ protein antibodies. N Engl F Med 1987; 317: 265-71.

24 Asherson R A, Khamashta M A, Gil A, et al. Cerebrovascular disease and antiphospholipid antibodies in systemic lupus erythematosus, lupus-like disease, and the primary antiphospholipid syndrome. Am $\mathcal{F}$ Med 1989; 86: $391-9$.

25 Mackworth-Young C. Antiphospholipid antibodies: more than just a disease marker? Immunol Today 1990; 11: $60-5$.

26 Teplizki H, Buskila D, Argov S, et al. Low serum antimycobacterial glycolipid antibody titers in the sera of patients with systemic lupus erythematosus associated with central nervous system involvement. $\mathcal{F}$ Rheumatol 1987; 14: 507-11.

27 Hirano T, Hashimoto H, Shiokawa Y. Antiglycolipid autoantibody detected in the sera from systemic lupus erythematosus patients. 7 Clin Invest 1980; 66: 1437-40.

28 Furukawa $F$, Kashihara-Sawami $M$, Lyons M B, Norris D A. Binding of antibodies to the extractable nuclear antigens SS-A/Ro and SS-B/La is induced on the surface of human keratinocytes by ultraviolet light (UVL): implications for the pathogenesis of photosensitive cutaneous lupus. F Invest Dermatol 1990; 94: 77-85.

29 Cutaneous lupus. F Invest Dermatol 1990; 94: 77-85. Reichlin $M$. Autoantibodies to the ribosomal P proteins react with a plasma membrane-related target on human react with a plasma membrane-related
cells. $\mathcal{F}$ Clin Invest 1992; 89: 1236-41.

30 Behan P, Geschwind N. Dyslexia, congenital anomalies, and immune disorders: the role of the fetal environment. Ann NY Acad Sci 1985; 457: 13-8.

31 Geschwind N, Behan P. Left-handedness: association with immune disease, migraine, and developmental learning disorder. Proc Natl Acad Sci USA 1982; 79: 5097-100.

32 Hanson V G, Horowitz $M$, Rosenbluth D, Spiera $H$ Puszkin S. Systemic lupus erythematosus patients with central nervous system involvement show autoantibodies to a $50-\mathrm{kD}$ neuronal membrane protein. $\mathcal{F}$ Exp Med 1992; 176: 565-73.

33 Sakic B, Szechtman H, Keffer M, Talangbayan H, Stead R, Denburg J A. A behavioural profile of autoimmune lupus-prone MRL mice. Brain Behav Immun 1992; 6: 265-85. 